\title{
Estudo envolvendo a função das imagens associadas a tópicos de Física Moderna nos livros didáticos do ensino médio
}

Cleci Teresinha Werner da Rosa

Marivane de Oliveira Biazus ${ }^{1}$

Luiz Marcelo Darroz ${ }^{1}$

Universidade de Passo Fundo

Passo Fundo - RS

\section{Resumo}

O estudo refere-se a uma investigação a respeito das imagens presentes nos livros didáticos de Física do ensino médio aprovados pelo Programa Nacional do Livro Didático (PNLD) 2018. O objetivo foi avaliar como essas imagens estão sendo utilizadas pelos autores para ilustrar os tópicos de Física Moderna referentes à radiação do corpo negro, ao efeito fotoelétrico, aos modelos atômicos e à espectroscopia. Como suporte teórico, adotou-se a taxonomia proposta por Perales e Jiménez (2002) para analisar a relação e a função das imagens junto ao texto. Os resultados desse estudo indicam que as obras apresentam uma grande diversidade na maneira como as imagens são apresentadas e que é necessário haver cuidado com as relações estabelecidas entre a imagem e o texto nesse recurso didático, visto que desempenham importante papel no processo de ensino e aprendizagem.

Palavras-chave: Imagens; Física Moderna; Livros Didáticos.

\begin{abstract}
The study refers to an investigation about the images that are presented inside the Physics' didact books of High School approved by the National Program of Didact Book (Programa Nacional do Livro Didáti-

\footnotetext{
${ }^{+}$Study involving the function of images associated with Modern Physics topics in high school textbooks

* Recebido: março de 2019. Aceito: janeiro de 2020.

${ }^{1}$ E-mails: cwerner@upf.br; marivanebiazus@gmail.com; 1darror@upf.br
} 
co) 2018. The main goal was to measure how these images are being used by the authors to illustrate the topics of Modern Physics regarding the black body radiation, the photoelectric effect, the atomic models and the spectroscopy. As theoretical support, it was adopted the taxonomy proposed by Perales e Jiménez (2002) to analyse the relation and the function of the images attached to the text. The results of this research indicate that the books present a big variety in the way how the images are presented and that being careful with the relation established between the image and the text in this didact resource is necessary, once they perform an important paper in the process of teaching and learning.

Keywords: Images; Modern Physics; Didact Books.

\section{Introdução}

A Base Nacional Comum Curricular (BNCC) sinaliza que no ensino médio a área de Ciências da Natureza, à qual a disciplina de Física faz parte, deve proporcionar aos estudantes a construção de um conhecimento contextualizado contribuindo para sua formação integral e cidadã. $\mathrm{O}$ ensino nesta área, deve fornecer condições aos jovens de aprofundarem o exercício do pensamento crítico, de compreender o seu contexto sob diferentes perspectivas, considerando-se a sua linguagem, os procedimentos e as teorias que lhes são intrínsecas. Além disso, aponta que ensino nessa área deve permitir ao educando a capacidade de tomar decisões e intervir em seu meio de forma responsável e ética, oportunizando a compreensão do "papel do conhecimento científico e tecnológico na organização social, nas questões ambientais, na saúde humana e na formação cultural, ou seja, analisar as relações entre ciência, tecnologia, sociedade e ambiente" (BRASIL, 2017, p. 549).

Considerando-se o mencionado sobre o ensino na área das Ciências da Natureza no ensino médio, ressalta-se a importância da apropriação por parte dos estudantes de conhecimentos atuais, em especial, os oriundos da Física Moderna. Os conhecimentos produzidos neste campo, datados ainda no início do século XX, modificaram o pensamento científico e oportunizaram o desenvolvimento de tecnologias. A esse respeito, Terrazan (1994) coloca que a importância da abordagem desses conhecimentos desde a escolarização básica, decorre do seu extenso campo de aplicação, em especial, em dispositivos de uso cotidiano dos estudantes, como é o caso do telefone celular, dos computadores, sensores, dentre outros tantos equipamentos presentes no dia a dia. Nesse contexto, a necessidade de inseri-la no ensino médio não se impõe para fins de mera atualização curricular, mas pelo fato de ela fazer parte da cultura, como qualquer outra manifestação científica, devendo ser estudada, discutida, trabalhada, enfim, aproveitada no sentido mais amplo da palavra.

A inserção da Física Moderna como conteúdo curricular na educação básica vem sendo discutida nas últimas décadas por pesquisadores, professores e documentos oficiais 
(TERRAZZAN, 1994; SILVA; KAWAMURA, 2001; OSTERMANN; MOREIRA, 2004; MACHADO; NARDI, 2006; CHAVES, 2010; FERREIRA, 2013). O foco das discussões, segundo os autores mencionados, tem sido a forma como esses conteúdos podem ser integrados ao componente curricular Física, possibilidades de abordagens metodológicas, situações de aproximações com o mundo vivencial dos alunos, dentre outros aspectos.

Em face disso, os livros didáticos para o ensino de Física vêm, a cada edição, inserindo de forma mais intensa aspectos relacionados à temática, mesmo que ainda haja divergências nos tópicos abordados, como mostraram Biazus (2015) e Giacomelli (2016). Os autores, em suas dissertações de mestrado, vinculados aos estudos da Mecânica Quântica e Relatividade Geral e Restrita, respectivamente, evidenciaram que as obras didáticas de ensino médio apresentam falta de consenso sobre quais aspectos devem ser abordados. A razão para isso estaria, no entendimento desses autores, na recente inclusão dos conteúdos nas obras e a falta da consolidação de um processo de transposição didática.

Contudo, apesar dessa falta de consenso entre os autores dos livros didáticos, há, especialmente na Física Moderna, elementos de ordem didática que se revelam escolhas comuns entre os autores. Uma delas é o uso das imagens como forma de abordar o conteúdo e melhorar a explicação, cuja importância didática é destacada por Martins, Gouvêa e Piccinini (2005), ao mencionarem que elas representam um importante recurso para comunicação e constituição das ideias científicas e sua conceitualização.

Limitando-se às imagens presentes nos livros didáticos, percebe-se, como assinalado por Araújo, Fernandes e Silva Junior (2013) que há uma avançada qualidade gráfica. Além disso, identifica-se que essas imagens estão presentes em diversos momentos do livro texto, desde a abordagem dos conteúdos, contextualização, exercícios, sugestões de atividades experimentais, entre outras. Isso possibilita aos estudantes realizar comparações, estabelecer relações, elaborar registros entre outros procedimentos desenvolvidos em sua aprendizagem.

Perales e Jimenez (2002, apud LEVIE; LENTZ, 1982), colocam que as imagens apresentam um efeito positivo e significativo tanto em termos de compreensão do texto quanto em termos de recuperação das informações pela memória. As imagens podem despertar no leitor reações emocionais, tornando mais atraente a leitura e substituir as palavras muito bem, fornecendo informações extralinguísticas de maneira mais eficaz. Mas, por outro lado, podem ser apenas elementos atrativos no texto, não contribuindo para a aprendizagem. Além disso, em situações complexas há a necessidade do acompanhamento de explicações junto às imagens para que o leitor possa se beneficiar desse recurso.

Otero e Greca (2004), também apresentam algumas implicações do uso de imagens para a aprendizagem em Física. Uma das implicações mencionadas pela autora refere-se à apresentação das imagens nos livros didáticos. Segundo a autora, as imagens são consideradas evidentes e transparentes, ignorando o fato de que há uma interpretação do sujeito frente a representação. Outra implicação é a forma simplificada e explícita do conhecimento proporcionado pelo recurso visual, que pode não favorecer a discussão, a compreensão em um nível 
cognitivo mais elevado e a interpretação do aluno. Assim como pode não colaborar para a construção de um modelo mental dos fenômenos. Essas implicações são de grande importância, e precisam ser refletidas pelos professores, que ao escolher e utilizar as imagens devem auxiliar os alunos no sentindo de construir uma análise crítica sobre o conhecimento que é representado.

Diante do exposto, especialmente da importância pedagógica do uso das imagens e a necessária cautela que se deve ter frente ao seu uso, surge o problema de pesquisa a ser explorado neste texto: como as imagens estão sendo utilizadas pelos autores dos livros didáticos de Física para abordar os conteúdos vinculados à Física Moderna?

Dessa forma, a presente pesquisa dedica-se a avaliar como as ilustrações estão sendo utilizadas pelos autores dos livros didáticos de Física do ensino médio em Física Moderna, considerando a sua relação com os fenômenos e conceitos que representam. Para tanto, estabelece como recorte o estudo dos tópicos: radiação do corpo negro, efeito fotoelétrico, modelos atômicos e espectroscopia. A delimitação desses referidos tópicos foi uma escolha entre os pesquisadores por se tratarem de conteúdos presentes em grande parte das obras indicadas no Plano Nacional do Livro Didático (PNLD) em 2018, como veremos na continuidade do texto.

A seguir, procede-se à identificação das obras selecionadas para o estudo e o referencial a ser adotado como subsídio para a presente análise.

\section{O livro didático e o uso das imagens no ensino de Física}

O livro didático representa um instrumento de grande importância no contexto escolar, pois se constitui em um material que, juntamente com outros aspectos como os conhecimentos obtidos pelo professor durante a sua formação e atuação profissional, norteiam o processo de ensino-aprendizagem na sala de aula. Além disso, Oliveira e Guimarães (1984) destacam que o livro didático passou por uma grande evolução e isso fez com que se tornasse um veículo de atualização de conhecimento para os professores.

Santos e Martins (2011), por sua vez, concluíram em seu trabalho que o livro didático, independentemente do seu contexto, dentro ou fora da escola, é um instrumento de grande importância no sentido de disseminar um conhecimento universal, capaz de modificar a identidade do indivíduo e promover uma sociedade mais igualitária. Destacam, ainda, que muitos autores consideram o livro didático como o melhor instrumento didático presente na sala de aula e, por esse motivo, merece uma atenção cuidadosa na sua construção, avaliação e utilização.

Analisando a importância do livro didático na educação brasileira, Lajolo (1996, p. 4) coloca que: 
Sua importância aumenta ainda mais em países como o Brasil, onde uma precaríssima situação educacional faz com que ele acabe determinando conteúdos e condicionando estratégias de ensino, marcando, pois, de forma decisiva, o que se ensina e como se ensina o que se ensina.

A autora enfatiza que nenhum livro, por melhor que seja, pode ser utilizado sem adaptações, e a escolha do livro didático mais apropriado ao contexto deve ser realizada pelo professor. É necessário que essa escolha e o uso do livro didático sejam de forma consciente por parte do professor, que deverá planejar as atividades escolares, avaliar o conteúdo apresentado e, de certa forma, reescrevê-lo, imprimindo a sua prática pedagógica.

No intuito de oferecer materiais de qualidade para subsidiar o trabalho pedagógico do professor e distribuir coleções de livros didáticos a alunos da educação básica de todo o país, o governo federal instituiu dois programas assim denominados: o PNLD - Plano Nacional do Livro Didático, voltado para o ensino fundamental; e o PNLEM - Programa Nacional do Livro do Ensino Médio, voltado à essa etapa de escolarização. Antes de serem enviados às escolas, os livros didáticos devem atender a diversos critérios relacionados à qualidade física e a aspectos conceituais, metodológicos e éticos, os quais são avaliados por uma comissão técnica para garantir a qualidade da obra, e então o professor poderá fazer a escolha do material que é mais adequado ao seu contexto.

No que se refere aos livros didáticos de Física, a distribuição gratuita aos alunos do ensino médio da rede pública teve início no ano de 2009. A utilização do livro didático de Física representou um grande avanço ao ensino, trazendo a superação de um modelo de aula, o qual era baseado na cópia de conteúdo e exercícios do quadro de giz pelos alunos, conforme explicita Garcia (2011). A partir da distribuição de 2009, passou-se a ter um aumento no número de obras que têm atendido aos critérios estabelecidos pelo PNLEM, permitindo, desse modo, um número maior de opções de seleção para o professor.

Moraes (2011, p. 1) destaca que "o livro didático de Física desempenha importância fundamental no ensino dessa disciplina, principalmente na Educação Básica”. O livro é a principal referência no ambiente escolar e local de acesso aos conteúdos de Física. No seu estudo, ele faz um resgate histórico, no qual destaca as relações entre as mudanças ocorridas nos livros didáticos e o ensino decorrente da legislação e da própria necessidade de mudança do ensino. Ressalta, também, que há uma dependência mútua entre o livro didático e o ensino de Física.

Considerando-se a importância do livro didático de Física no contexto escolar, podese dizer que é também um dos instrumentos apropriados para estabelecer a relação entre imagem, conhecimento científico e o ensino-aprendizagem de Física. O uso de imagens é uma importante estratégia para o ensino, pois é capaz de chamar a atenção, despertar o interesse para o conteúdo abordado e facilitar a compreensão dos fenômenos físicos. 
Perales e Jiménez (2002) destacam que a utilização dos recursos visuais oferece diferentes funções didáticas, algumas das quais são apresentadas na revisão de literatura realizada por eles. Essas funções podem:

- Ilustrar, ou seja, torná-los mais atrativos para despertar o interesse dos leitores;

- Descrever situações ou fenômenos baseando-se na capacidade humana de processar a informação visual e a sua vantagem frente aos textos escritos na estimulação dos modelos mentais;

- Explicar as situações descritas. Isto é, nesse caso, as ilustrações não mostram apenas o mundo, mas também o que o transforma com a intenção de evidenciar relações ou ideias não evidentes por si mesmas, a fim de facilitar a compreensão por parte do leitor (PERALES; JIMÉNEZ, 2002, p. 372).

Martins, Gouvêa e Piccinini (2005), analisaram as imagens apresentadas nos livros de ciências do ensino fundamental, como os alunos faziam a leitura dessas imagens e como os professores trabalhavam essas imagens. No que se refere à leitura realizada pelos alunos, eles destacam que as imagens estimulam o uso de uma grande variedade de estratégias, permitem que os conhecimentos prévios tenham um papel ativo no processo, que experiências de leituras anteriores sejam integradas e contextualizadas com as ilustrações analisadas, dentre vários outros benefícios. Os autores ainda ressaltam que o uso de imagens no ensino de ciências permite uma maior participação dos alunos, influenciando a memorização dos conceitos e possibilitando a aproximação de um universo invisível e inacessível pelos alunos.

Perales (2006) chama a atenção de que a eficácia didática de uma imagem está diretamente relacionada à sua capacidade de representar o conteúdo com o qual se relaciona. Segundo ele, é necessário que as ilustrações sejam selecionadas de forma cuidadosa e que, assim como nos textos, é necessário interpretar e até mesmo verificar erros com o intuito de promover a aprendizagem. Outro ponto destacado pelo autor refere-se ao fato de que as imagens auxiliam mais em textos complexos do que nos simples, e ainda que, juntamente com o texto, as imagens devem formar um corpo de informação coerente e que, quanto mais integrado, maior a eficiência desse recurso.

Em outro estudo, Darroz, Rosa e Giaretta (2016) buscaram investigar o uso de imagens esportivas no ensino de mecânica, presentes nos livros didáticos de Física. Foram analisadas 444 imagens presentes nos quatorze livros indicados pelo PNLD 2015 e categorizados seguindo a proposta de Perales e Jiménez (2002). Os resultados indicaram que as ilustrações relacionadas aos esportes têm sido utilizadas para a apresentação de conceitos de mecânica. Essas imagens, em sua maioria, são fotografias que retratam situações reais, são de simples compreensão pelo aluno e procuram prender a atenção. Os autores alertam para o fato de muitas imagens não possuírem uma relação com o texto e também não promoverem situações de problematização dos conceitos.

É importante considerar que o uso inadequado de imagens pode não contribuir para a construção de sentidos e significados científicos, além de dificultar o entendimento do aluno, 
levando-o a erros conceituais. Nesse sentido, muitos pesquisadores (PERALES; JIMÉNEZ, 2002; OTERO; MOREIRA; GRECA et al., 2002; MONTEIRO; JUSTI, 2000) têm apontado que as imagens presentes nos livros didáticos vêm aumentando de forma significativa e apresentando um design gráfico cada vez mais atraente, mas poucas contribuem para a aprendizagem. Muitas dessas ilustrações não permitem que os leitores estabeleçam, por si mesmos, os vínculos necessários entre os conceitos representados e o texto que os acompanha. Além de se apresentarem apenas como imagens meramente ilustrativas.

\section{Pesquisa}

Para a realização da pesquisa foram utilizados os livros de Física aprovados pelo PNLD em 2018, totalizando doze livros. Nesta busca foram investigados os livros que correspondem ao terceiro ano do ensino médio, por ser a etapa em que se encontram os tópicos referentes à Física Moderna. Os livros analisados são descritos no Quadro 1.

Quadro 1 - Livros Didáticos de Física.

\begin{tabular}{|c|c|c|c|c|c|}
\hline Código & Livro & Autor & Editora & Edição & Ano \\
\hline A & $\begin{array}{l}\text { Física contexto e } \\
\text { aplicações }\end{array}$ & Antônio Máximo; Beatriz Alvarenga. & Scipione & $2^{\mathrm{a}}$ & 2016 \\
\hline $\mathrm{B}$ & Física aula por aula & Benigno Barreto; Claudio Xavier & FTD & $3^{\mathrm{a}}$ & 2016 \\
\hline $\mathrm{C}$ & $\begin{array}{l}\text { Física: Ciência e } \\
\text { Tecnologia }\end{array}$ & $\begin{array}{l}\text { Carlos Magno A. Torres; Nicolau Gilberto } \\
\text { Ferraro; Paulo Antonio de Toledo Soares; } \\
\text { Paulo Cesar Martins Penteado. }\end{array}$ & Moderna & $4^{\mathrm{a}}$ & 2016 \\
\hline $\mathrm{D}$ & $\begin{array}{l}\text { Ser protagonista } \\
\text { Física }\end{array}$ & $\begin{array}{l}\text { Adriana Benetti Marques Válio; Ana } \\
\text { Fukui; Bassam Ferdinian, Gladstone Al- } \\
\text { varenga de Oliveira; Madson de Melo } \\
\text { Molina; Venê. }\end{array}$ & $\begin{array}{l}\text { Edições } \\
\text { SM }\end{array}$ & $3^{\mathrm{a}}$ & 2016 \\
\hline $\mathrm{E}$ & $\begin{array}{l}\text { Física: interação e } \\
\text { tecnologia }\end{array}$ & Aurélio Gonçalves Filho; Carlos Toscano. & Leya & $2^{\mathrm{a}}$ & 2016 \\
\hline $\mathrm{F}$ & Física & $\begin{array}{l}\text { Gualter José Biscuola; Newton Villas } \\
\text { Bôas; Ricardo Helou Doca. }\end{array}$ & Saraiva & $3^{\mathrm{a}}$ & 2016 \\
\hline G & $\begin{array}{l}\text { Física para o ensino } \\
\text { médio }\end{array}$ & Luiz Felipe Fuke; Kazuhito Yamamoto. & Saraiva & $4^{\mathrm{a}}$ & 2017 \\
\hline $\mathrm{H}$ & Física & $\begin{array}{l}\text { José Roberto Bonjorno; Regina de Fátima } \\
\text { Souza Azenha Bonjorno; Valter Bonjorno; } \\
\text { Clinton Marcico Ramos; Eduardo de Pinho } \\
\text { Prado; Renato Casemiro. }\end{array}$ & FTD & $3^{\mathrm{a}}$ & 2016 \\
\hline I & $\begin{array}{l}\text { Conexões com a } \\
\text { Física }\end{array}$ & $\begin{array}{l}\text { Gloria Martini; Walter Spinelli; Hugo } \\
\text { Carneiro Reis; Blaidi Sant'Anna. }\end{array}$ & Moderna & $3^{\mathrm{a}}$ & 2016 \\
\hline $\mathrm{J}$ & Física & $\begin{array}{l}\text { José Roberto Castilho Piqueira; Wilson } \\
\text { Carron; José Osvaldo de Souza Guima- } \\
\text { rães. }\end{array}$ & Ática & $2^{\mathrm{a}}$ & 2016 \\
\hline $\mathrm{K}$ & Física em contextos & $\begin{array}{l}\text { Maurício Pietrocola; Alexander Pogibin; } \\
\text { Renata de Andrade; Talita Raquel Rome- } \\
\text { ro. }\end{array}$ & $\begin{array}{l}\text { Editora do } \\
\text { Brasil }\end{array}$ & $1^{\circ}$ & 2016 \\
\hline $\mathrm{L}$ & $\begin{array}{l}\text { Compreendendo a } \\
\text { Física }\end{array}$ & Alberto Gaspar. & Ática & $3^{\mathrm{a}}$ & 2016 \\
\hline
\end{tabular}

Fonte: Dados da pesquisa (2019). 
Conforme expresso mais adiante (Quadro 13), os tópicos de Física Quântica elencados para investigação no presente estudo, não representam unanimidade entre os autores, de modo que nem todos os livros contemplam os quatro tópicos (Radiação do corpo negro, Efeito Fotoelétrico, Modelos Atômicos e Espectroscopia).

Para a análise das imagens utilizadas nas referidas obras, recorreu-se ao estudo de Perales e Jiménez (2002). Nesse estudo, os autores propõem seis categorias que servem para avaliar as imagens utilizadas pelos autores das obras, a saber: sequência didática, iconicidade, funcionalidade, relação com o texto principal, etiquetas verbais e conteúdo científico.

Os autores apresentam subcategorias, as quais denominam de "unidades elementares", com o intuito de tornar a análise mais minuciosa. A seguir, são descritas de forma detalhada essas categorias e suas respectivas unidades elementares, além dos objetivos de cada uma para a análise dos dados levantados.

\section{III.1 Sequência didática}

A categoria sequência didática avalia as afirmações, referências e problemas apresentados pelos autores dos livros didáticos ao longo do texto que antecede e sucede a imagem, mostrando se houve um planejamento didático e uma sequência dos conceitos apresentados. Essa categoria divide-se em seis unidades elementares, conforme indicado no Quadro 2.

Quadro 2 - Unidades elementares para a análise da sequência didática.

\begin{tabular}{|l|l|}
\hline \multicolumn{1}{|c|}{ Unidade } & \multicolumn{1}{c|}{ Definição } \\
\hline Evocação & $\begin{array}{l}\text { O texto se refere a um fato do cotidiano ou conceito que se supõe conhecido pelo } \\
\text { aluno. }\end{array}$ \\
\hline Definição & O significado de um termo novo é estabelecido no contexto teórico. \\
\hline Aplicação & É um exemplo que estende ou consolida uma definição \\
\hline Descrição & $\begin{array}{l}\text { O texto faz referência a fatos ou eventos do cotidiano que se supõem serem desco- } \\
\text { nhecidos pelo leitor. Também se incluem nessa unidade conceitos necessários para } \\
\text { a discussão do tópico principal. }\end{array}$ \\
\hline Interpretação & São utilizados conceitos teóricos para explicar os eventos experimentais. \\
\hline Problematização & $\begin{array}{l}\text { No texto há questões que não podem ser respondidas com os conceitos jé desen- } \\
\text { volvidos. }\end{array}$ \\
\hline
\end{tabular}

Fonte: Perales e Jiménez (2002).

\section{III.2 Iconicidade}

Na categoria iconicidade é estabelecido um grau de simbolização, no qual as imagens se assemelham ao objeto representado por ela. Desse modo, as imagens que possuem um grau de iconicidade maior são menos abstratas, ou seja, mais realistas, como, por exemplo, uma fotografia, ao passo que as de grau de iconicidade menor são mais abstratas, exigindo um conhecimento do código simbólico maior, como um esquema. Nessa categoria, encontram-se sete unidades elementares, conforme explicitado no Quadro 3. 
Quadro 3 - Unidades elementares para a análise do grau de iconicidade.

\begin{tabular}{|l|l|}
\hline \multicolumn{1}{|c|}{ Unidade } & \multicolumn{1}{c|}{ Definição } \\
\hline Fotografia & Apresenta o espaço por meio de fotos. \\
\hline Desenho figurativo & $\begin{array}{l}\text { Valoriza a representação orgânica mostrando os objetos mediante a imitação da } \\
\text { realidade }\end{array}$ \\
\hline $\begin{array}{l}\text { Desenho figurativo }+ \\
\text { signos }\end{array}$ & $\begin{array}{l}\text { Representa ações ou magnitudes inobserváveis em um espaço de representação } \\
\text { heterogêneo. }\end{array}$ \\
\hline $\begin{array}{l}\text { Desenho figurativo }+ \\
\text { signos normalizados }\end{array}$ & $\begin{array}{l}\text { A ilustração apresenta figurativamente uma situação e paralelamente se represen- } \\
\text { tam alguns aspectos mediante o uso de signos normalizados. }\end{array}$ \\
\hline Desenho esquemático & Valoriza as representações das relações sem se importar com os detalhes. \\
\hline $\begin{array}{l}\text { Desenho esquemático } \\
+ \text { signos }\end{array}$ & Representa ações ou magnitudes inobserváveis. \\
\hline $\begin{array}{l}\text { Desenho esquemático }+ \\
\text { signos normalizados }\end{array}$ & $\begin{array}{l}\text { A ilustração constitui um espaço de representação homogêneo e simbólico com } \\
\text { regras sintáticas específicas. }\end{array}$ \\
\hline
\end{tabular}

Fonte: Perales e Jiménez (2002).

\section{III.3 Funcionalidade}

A funcionalidade busca analisar se a utilização das imagens como forma de representação de uma ideia facilita o entendimento de um conceito científico. Para tal, há uma grande diversidade de meios de representação como: desenho manual, símbolos e códigos ou representação gráfica. No entanto, é necessário que haja uma alfabetização gráfica pelos alunos para que esta, de fato, possa contribuir neste entendimento (PERALES; JIMÉNEZ, 2002). Essa categoria apresenta três unidades elementares, conforme o Quadro 4.

Quadro 4- Unidades elementares para a análise da funcionalidade das imagens.

\begin{tabular}{|l|l|}
\hline \multicolumn{1}{|c|}{ Unidade } & \multicolumn{1}{c|}{ Definição } \\
\hline Inoperante & A ilustração não apresenta nenhum elemento utilizável, apenas cabe observá-la. \\
\hline Operativa elementar & A ilustração contém elementos de representação universal. \\
\hline Sintática & A ilustração contém elementos que exigem o conhecimento de normas específicas. \\
\hline
\end{tabular}

Fonte: Perales e Jiménez (2002).

\section{III.4 Relação com o texto principal}

A categoria relação com o texto principal busca investigar se o texto narrativo ou argumentativo utilizado pelos autores do LD apresenta relação com os recursos visuais. As informações contidas nas imagens muitas vezes são descontínuas e, por si só, não expressam o completo significado quando separadas do texto, o que torna necessária uma dupla codificação. Ela possui três unidades elementares, conforme descrito no Quadro 5. 
Quadro 5 - Unidades elementares para a análise da relação com o texto principal.

\begin{tabular}{|l|l|}
\hline \multicolumn{1}{|c|}{ Unidade } & \multicolumn{1}{c|}{ Definição } \\
\hline Conotativa & $\begin{array}{l}\text { O texto descreve os conteúdos sem mencionar sua correspondência com os elementos } \\
\text { incluídos na ilustração. Supostamente, estas relações são óbvias e o leitor pode fazê-las. }\end{array}$ \\
\hline Denotativa & $\begin{array}{l}\text { O texto estabelece a correspondência entre os elementos contidos na ilustração e os } \\
\text { conteúdos representados. }\end{array}$ \\
\hline Sinóptica & $\begin{array}{l}\text { O texto descreve a correspondência entre os elementos da ilustração e os conteúdos } \\
\text { representados. Além disso, estabelece as condições nas quais as relações entre os ele- } \\
\text { mentos inclusos na ilustração representam as relações entre os conteúdos, de modo que } \\
\text { a imagem e o texto formam uma unidade indivisível. }\end{array}$ \\
\hline
\end{tabular}

Fonte: Perales e Jiménez (2002).

\section{III.5 Etiquetas verbais}

A categoria etiquetas verbais refere-se aos textos presentes nas ilustrações, que auxiliam em sua interpretação. Apesar de essa categoria se parecer com a anterior, o fato de o texto estar na própria ilustração ou ser externo a ela permite distinguir uma ilustração autossuficiente de uma dependente do texto não ilustrado. Essa categoria possui as unidades elementares: sem etiqueta, nominativa e relacionável, conforme especificado no Quadro 6.

Quadro 6 - Unidades elementares para a análise das etiquetas verbais.

\begin{tabular}{|l|l|}
\hline \multicolumn{1}{|c|}{ Unidade } & \multicolumn{1}{c|}{ Definição } \\
\hline Sem etiqueta & A ilustração não contém nenhum texto. \\
\hline Nominativa & Contém letras ou palavras que identificam alguns elementos da ilustração. \\
\hline Relacionável & Textos que descrevem as relações entre os elementos da ilustração. \\
\hline
\end{tabular}

Fonte: Perales e Jiménez (2002).

\section{III.6 Conteúdo Científico}

A categoria conteúdo científico refere-se aos tópicos de Física Moderna: radiação do corpo negro, efeito fotoelétrico, modelos atômicos e espectroscopia, onde são quantificadas as ilustrações levando-se em consideração a relação destas com as ideias centrais de cada um dos tópicos. As definições das unidades elementares desta categoria estão contidas no Quadro 7.

Quadro 1 - Unidades elementares para a análise do conteúdo científico.

\begin{tabular}{|l|l|}
\hline \multicolumn{1}{|c|}{ Unidade } & \multicolumn{1}{c|}{ Definição } \\
\hline $\begin{array}{l}\text { Radiação do corpo } \\
\text { negro }\end{array}$ & $\begin{array}{l}\text { A ilustração indica a absorção ou emissão de radiação eletromagnética por corpos } \\
\text { com temperaturas diferentes da temperatura do ambiente. }\end{array}$ \\
\hline Efeito Fotoelétrico & $\begin{array}{l}\text { Imagens em que placas metálicas são expostas a uma radiação eletromagnética que } \\
\text { pode arrancar elétrons dessa placa. }\end{array}$ \\
\hline Modelos Atômicos & $\begin{array}{l}\text { Ilustrações que apresentam os diferentes modelos utilizados no contexto científico } \\
\text { para representar o átomo. }\end{array}$ \\
\hline Espectroscopia & $\begin{array}{l}\text { Ilustrações que demonstram a interação entre radiações eletromagnéticas com a } \\
\text { matéria. }\end{array}$ \\
\hline
\end{tabular}

Fonte: Dados da pesquisa (2019). 
As representações visuais dos livros didáticos foram avaliadas por três pesquisadores da área de ensino de Física, que procederam à análise das imagens referentes aos tópicos de Física Moderna presentes nos livros de Física aprovados pelo PNDL 2018. Após a avaliação de cada pesquisador, houve o confronto entre os resultados encontrados por cada um deles, de forma a verificar e resolver as divergências nesses resultados. Ressalta-se que a categorização das imagens não representa algo simples de realizar e está relacionada a critérios que em determinadas situações podem ser subjetivos, portanto, podendo haver divergências. Entretanto, após discussões e ponderações entre os três pesquisadores, obteve o consenso que está representado neste texto.

Salienta-se que foram selecionadas as representações do tipo fotografia, desenho, diagrama e esquema ao longo do texto principal, não sendo consideradas as representações presentes em exercícios ou sessões especiais contidas nas obras.

Para a realização da análise inicial, os pesquisadores avaliaram os recursos visuais selecionados, de acordo com as unidades elementares já descritas nas categorias: sequência didática, iconicidade, funcionalidade, relação com o texto principal, etiquetas verbais e conteúdo científico. De forma sistemática, os dados foram dispostos em uma tabela que esquematizava as categorias, as suas unidades elementares, os livros didáticos e os recursos visuais. Nos casos em que ocorreram divergências quanto às classificações propostas pelos pesquisadores, as imagens foram novamente avaliadas e discutidas pelos mesmos em conjunto, com a finalidade de se chegar a um consenso.

\section{Resultados e discussões}

A partir dos critérios descritos acima, foram analisadas as imagens presentes nos quatorze livros didáticos de Física indicados pelo PNLD 2018. Ao total foram investigadas, analisadas e categorizadas 121 imagens como apresentado na Fig. 1.

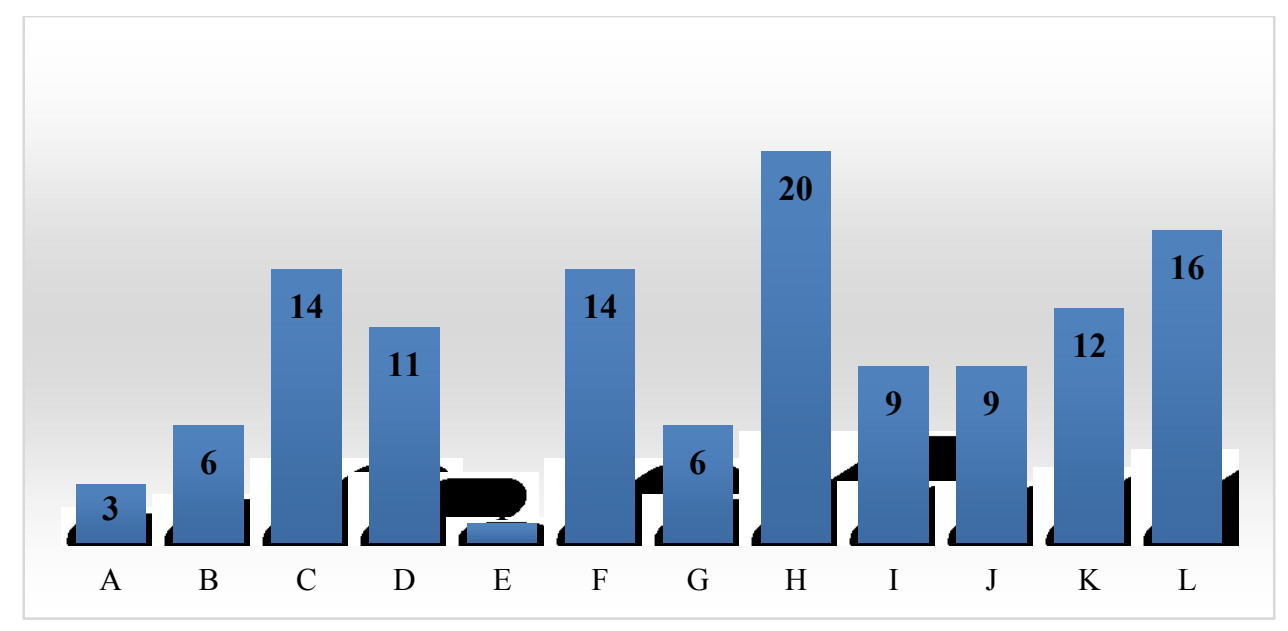

Fig. 1 -Distribuição de imagens por livro analisado. Fonte: Dados da pesquisa (2019). 
De maneira geral, destaca-se que todas as obras utilizam o recurso visual para a ilustração de conceitos relativos à Física Moderna. Nota-se no Quadro 8 que a quantidade de imagens que atendem aos critérios estabelecidos nessa investigação apresenta diferenças significativas entre uma obra e outra, como é o caso do livro E, o qual apresenta uma única imagem e o livro H vinte imagens. Tal variação pode recorrer do fato de que alguns autores apresentam uma quantidade maior de conteúdo para cada tópico analisado e por consequência uma quantidade maior de recursos visuais para ilustrá-los.

Quadro 2 - Categoria Sequência Didática.

\begin{tabular}{|l|c|c|c|c|c|c|c|c|c|c|c|c|c|}
\hline \multicolumn{10}{|c|}{ Sequência Didática } \\
\hline & A & B & C & D & E & F & G & H & I & J & K & L & Total \\
\hline Evocação & & & 2 & & & & & 1 & & 1 & & & 4 \\
\hline Definição & & & 1 & & & 1 & 2 & & 2 & & & 4 & 8 \\
\hline Aplicação & & 1 & 2 & & & 3 & 1 & 5 & & 1 & 1 & & 14 \\
\hline Descrição & 2 & 3 & 6 & 9 & 1 & 7 & 2 & 12 & 3 & 6 & 7 & 7 & 65 \\
\hline Interpretação & 1 & 1 & 3 & 1 & & 3 & 1 & 2 & 3 & 4 & 4 & 5 & 28 \\
\hline Problematização & & 1 & & 1 & & & & & 1 & & & & 3 \\
\hline
\end{tabular}

Fonte: Dados da pesquisa (2019).

Em relação à categoria sequência didática (Quadro 8) nota-se que a maioria das imagens se enquadra nas categorias de Aplicação, Descrição e Interpretação. Destaca-se, também, que entre todas as obras analisadas os recursos visuais do tipo descritivo são predominantes. Por exemplo, a Fig. 2b (livro C) é utilizada pelo autor para demonstrar como Rutherford detectou o comportamento das partículas alfa ao passarem por uma fina folha de ouro e, a partir disso, propor um novo modelo atômico. A imagem, juntamente com o texto, auxilia o aluno a compreender os resultados obtidos com esse experimento. Outra categoria elementar que apareceu com frequência entre as obras é a Interpretação, recurso pelo qual os autores buscam articular conceitos teóricos com os fenômenos. Isso pode ser evidenciado na Fig. 2a (livro F), em que a partir do modelo atômico proposto por Bohr um elétron pode saltar de um nível de energia para outro mais elevado e, ao retornar, emitir uma parte da radiação recebida. Na categoria Aplicação, os autores buscam mostrar imagens em que os conceitos abordados são aplicados à tecnologia como, por exemplo, a Fig. 2c (livro H), no qual o efeito fotoelétrico é mostrado através do funcionamento automático de abrir e fechar portas.

Observa-se, também, que a categoria Evocação aparece apenas nos livros C, H e J, o que pode ser justificado pelo fato de que os conceitos abordados pela Física Moderna não são conceitos que possam ser facilmente associados ao dia a dia do aluno, sendo, portanto, em sua grande maioria, conceitos abstratos e desconhecidos pelos alunos. Os livros que apresentaram imagens que se encaixaram a essa categoria mostraram imagens, por exemplo, de um forno com uma barra incandescente para abordar a radiação térmica, o que possivelmente não era desconhecido pelo aluno. Ainda, pode-se destacar que foi encontrada, nos livros B, D e I, uma 
imagem ligada à categoria elementar problematizadora, no qual os autores buscam instigar o aluno e levá-lo a testar suas concepções, como o que é mostrado na Fig. 2d (livro B).

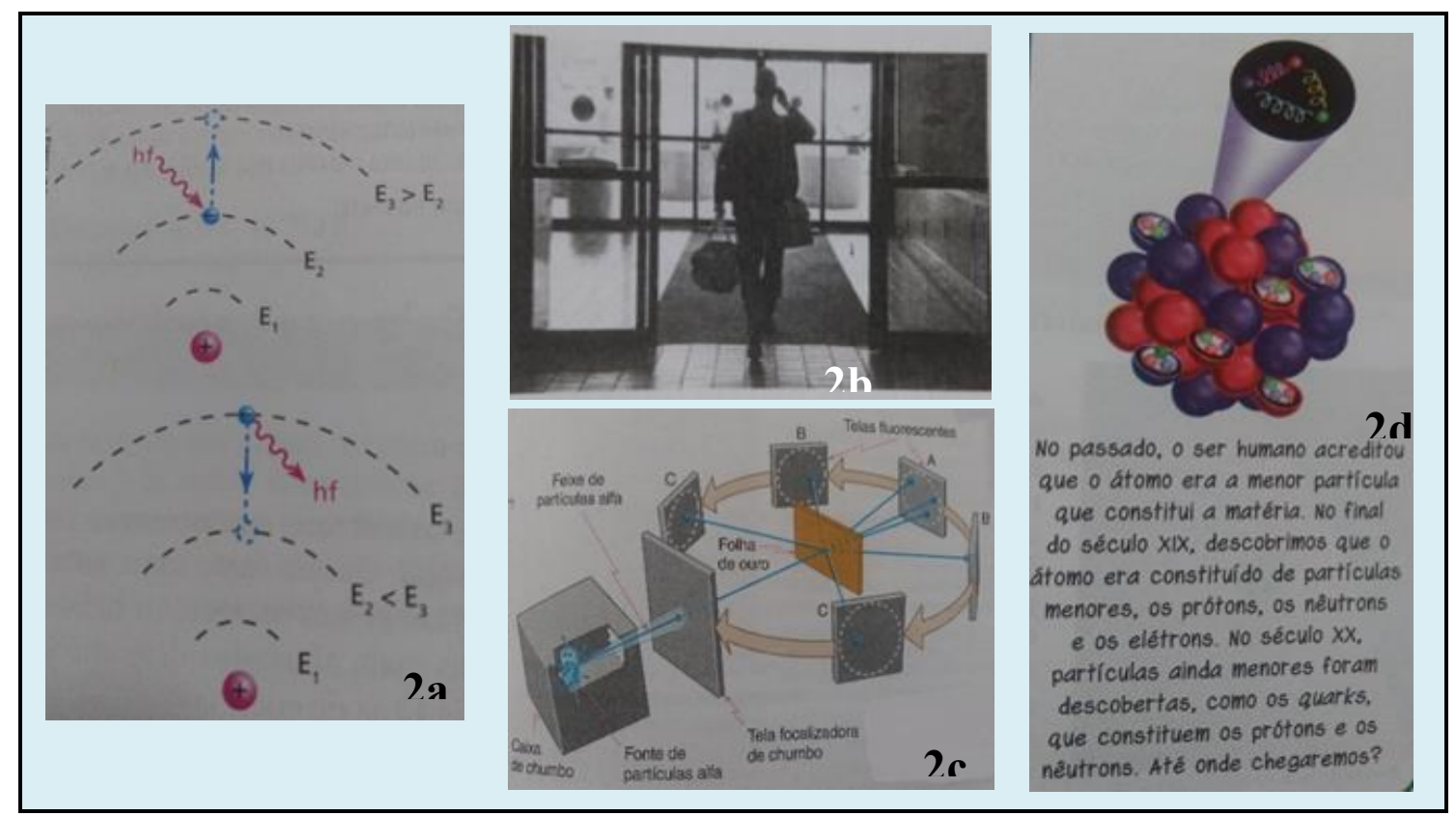

Fig. 2 - Exemplos dos recursos visuais quanto à sequência didática.

Fonte: Biscuola, Villas Bôas e Doca (2016) (2a-Livro F); Torres et al. (2016) (2bLivro C); Bonjorno et al. (2016) (2c-Livro H); Barreto e Xavier (2016) (2d - Livro B).

De forma mais sintética é possível destacar que nesta categoria os livros de Física não têm, em sua maioria, uma distribuição homogênea das imagens em consonância com o que é apresentado ao longo do texto. Algumas obras apresentam um número maior de imagens para descrever o fenômeno, por exemplo, enquanto que não utiliza imagens para definição, aplicação e problematização. Outro aspecto a ser apontado é a pouca utilização de imagens que busquem problematizar, ou seja, provocar o aluno a refletir sobre o conceito apresentado na imagem e ir além do texto apresentado. Destaca-se a pouca utilização de imagens ligadas ao cotidiano do aluno, fato esse que se tem por hipótese a dificuldade dos autores em representar conceitos bastante abstratos, que não se encontram visível e concretamente em situações cotidianas.

$\mathrm{Na}$ análise da categoria iconicidade (Quadro 9), observa-se que a fotografia não é um recurso visual utilizado pela maioria das obras. Dentre as que usam, destaca-se o livro $\mathrm{H}$, que apresenta seis fotografias, as quais são utilizadas para exemplificar situações reais, como por exemplo, a foto de uma porta que abre e fecha automaticamente para mostrar uma aplicação do efeito fotoelétrico. Nessa obra, ainda são usadas fotos de experimentos realizados em laboratório. As categorias referentes a desenho figurativo, desenho figurativo + signos e desenho figurativo + signos normalizados correspondem a cerca de $30 \%$ das imagens analisadas. Destaca-se que essas categorias buscam descrever situações mais próximas do real e diferenciam- 
se pela utilização de símbolos para complementar de forma abstrata o fenômeno analisado. A Fig. 3a (livro C), por exemplo, representa uma fotocélula ligada a uma bateria e, junto a ela, além de símbolos comuns à Física, utilizam-se setas para auxiliar na compreensão do seu funcionamento.

Quadro 3 - Categoria Iconicidade.

\begin{tabular}{|c|c|c|c|c|c|c|c|c|c|c|c|c|c|}
\hline \multicolumn{14}{|c|}{ Iconicidade } \\
\hline & $\mathbf{A}$ & B & $\mathbf{C}$ & D & $\mathbf{E}$ & $\mathbf{F}$ & $\mathbf{G}$ & $\mathbf{H}$ & I & $\mathbf{J}$ & $\mathbf{K}$ & $\mathbf{L}$ & Total \\
\hline Fotografia & & 1 & 2 & 1 & & & & 6 & & 2 & & & 12 \\
\hline Desenho figurativo & & & 1 & & & 2 & & 1 & & & 1 & 1 & 6 \\
\hline Desenho figurativo + signos & 1 & & 2 & 2 & & 2 & 1 & 3 & 4 & 3 & 2 & 2 & 22 \\
\hline Desenho figurativo + signos normalizados & & 1 & & & & 2 & 1 & & & & 2 & 3 & 9 \\
\hline Desenho esquemático & & & & 1 & & 2 & 1 & 1 & & & & & 5 \\
\hline Desenhos esquemático + signos & & 4 & 6 & 5 & 1 & & 1 & 7 & 4 & 4 & 1 & 3 & 36 \\
\hline Desenho esquemático + signos normalizados & 2 & & 3 & 2 & & 6 & 2 & 1 & & 4 & 6 & 7 & 34 \\
\hline
\end{tabular}

Fonte: Dados da pesquisa (2019).

Já as categorias desenho esquemático, desenho esquemático + signos e desenho esquemático + signos normalizados correspondem à cerca de $60 \%$ das imagens analisadas. Isso revela que há uma predominância de imagens abstratas, as quais exigem que o aluno interprete vários códigos simbólicos para a compreensão do fenômeno que está sendo mostrado. Isso pode ser evidenciado na Fig. 3b (livro J), na qual é mostrada a representação do modelo atômico proposto por Rutherford. Nessa imagem, os alunos devem interpretar que no núcleo estão as cargas positivas e na eletrosfera, os elétrons movimentando-se em camadas elípticas. Na Fig. 3c (livro L), para mostrar os resultados do experimento de Rutherford são utilizados símbolos que não exigem conhecimento específico do aluno, mas que permitem que ele consiga compreender, através do sentido das setas, o desvio que as partículas sofrem ao atingir o núcleo.

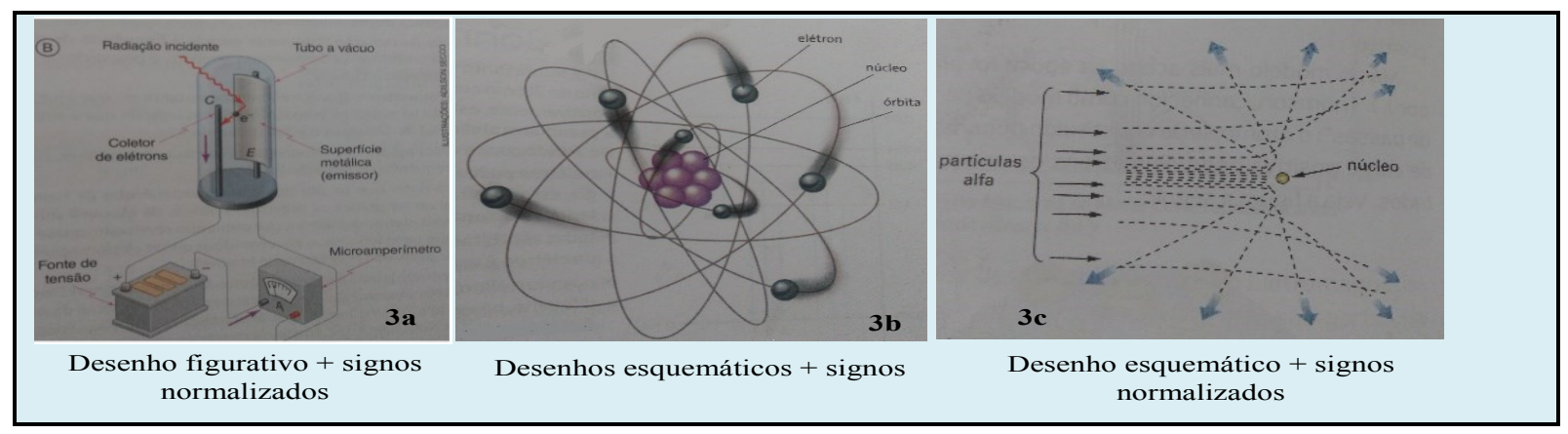

Fig. 3 - Exemplos dos recursos visuais em relação ao grau de iconicidade.

Fonte: Torres et al. (2016) (3a-Livro C); Piqueira et al. (2017) (3b-Livro J); Gaspar (2016) (3c-Livro L). 
Nessa categoria há um predomínio de desenhos esquemáticos para a representação do fenômeno, revelando um grau de complexidade maior das imagens que são apresentadas. A esse respeito pressupõe-se que haja uma tentativa por parte dos autores em buscar aproximar o aluno de conceitos não visíveis e palpáveis por ele. Podem ser citados, por exemplo, o uso dessas representações para descrever os modelos atômicos, experimentos realizados em laboratório e até mesmo analogias para melhor compreender e materializar o que o texto apresenta. É interessante destacar que há uma grande diferença nessas representações nas obras analisadas para os mesmos conceitos, denotando diferentes interpretações entre os autores.

Quadro 4 - Funcionalidade.

\begin{tabular}{|c|c|c|c|c|c|c|c|c|c|c|c|c|c|}
\hline \multicolumn{14}{|c|}{ Funcionalidade } \\
\hline & A & B & C & $\mathbf{D}$ & $\mathbf{E}$ & $\mathbf{F}$ & $\mathbf{G}$ & $\mathbf{H}$ & I & $\mathbf{J}$ & K & $\mathbf{L}$ & Total \\
\hline Inoperante & & 1 & 3 & 1 & & 2 & 1 & 7 & & 2 & 2 & 3 & 22 \\
\hline Operativa elementar & & 1 & 1 & 3 & & 6 & & 1 & 4 & 3 & 2 & 8 & 29 \\
\hline Sintática & 3 & 4 & 10 & 7 & 1 & 6 & 5 & 12 & & 7 & 8 & 4 & 72 \\
\hline
\end{tabular}

Fonte: Dados da pesquisa (2019).

Em relação à funcionalidade das imagens utilizadas para facilitar o entendimento dos conceitos apresentados (Quadro 10), destaca-se que todas as obras apresentam em sua maioria ilustrações que exigem do aluno conhecimentos específicos ou prévios para a sua compreensão, caracterizando a categoria elementar sintática. O livro C, por exemplo, possui aproximadamente $71,4 \%$ das imagens nessa unidade elementar. A Fig. 4c (livro I) mostra uma imagem desse tipo. Por outro lado, é interessante destacar que a unidade elementar inoperante, na qual as imagens possuem apenas um papel figurativo, não é muito utilizado pelos autores, conforme é apresentado na Fig. 4a (Livro C). Do mesmo modo, a unidade operativa elementar, unidade na qual são utilizados elementos universais também não são muito utilizadas. Um exemplo de imagem deste tipo é apresentado na Fig. 4b (Livro I), na qual o sinal negativo é utilizado para simbolizar um elétron.

A respeito da funcionalidade, as imagens apresentadas exigem conhecimentos específicos do estudante para o seu entendimento, além de uma compreensão maior entre o fenômeno e o plano simbólico. De modo geral é possível inferir que as imagens trazidas pelas obras têm buscado o uso de um nível cognitivo mais elevado por parte do estudante. Salientase também que a utilização de imagens apenas figurativas tem pouco espaço nas obras, denotando que os autores têm recorrido à utilização dos recursos visuais no sentindo de ajudar o aluno a compreender o conceito que está sendo apresentado. 


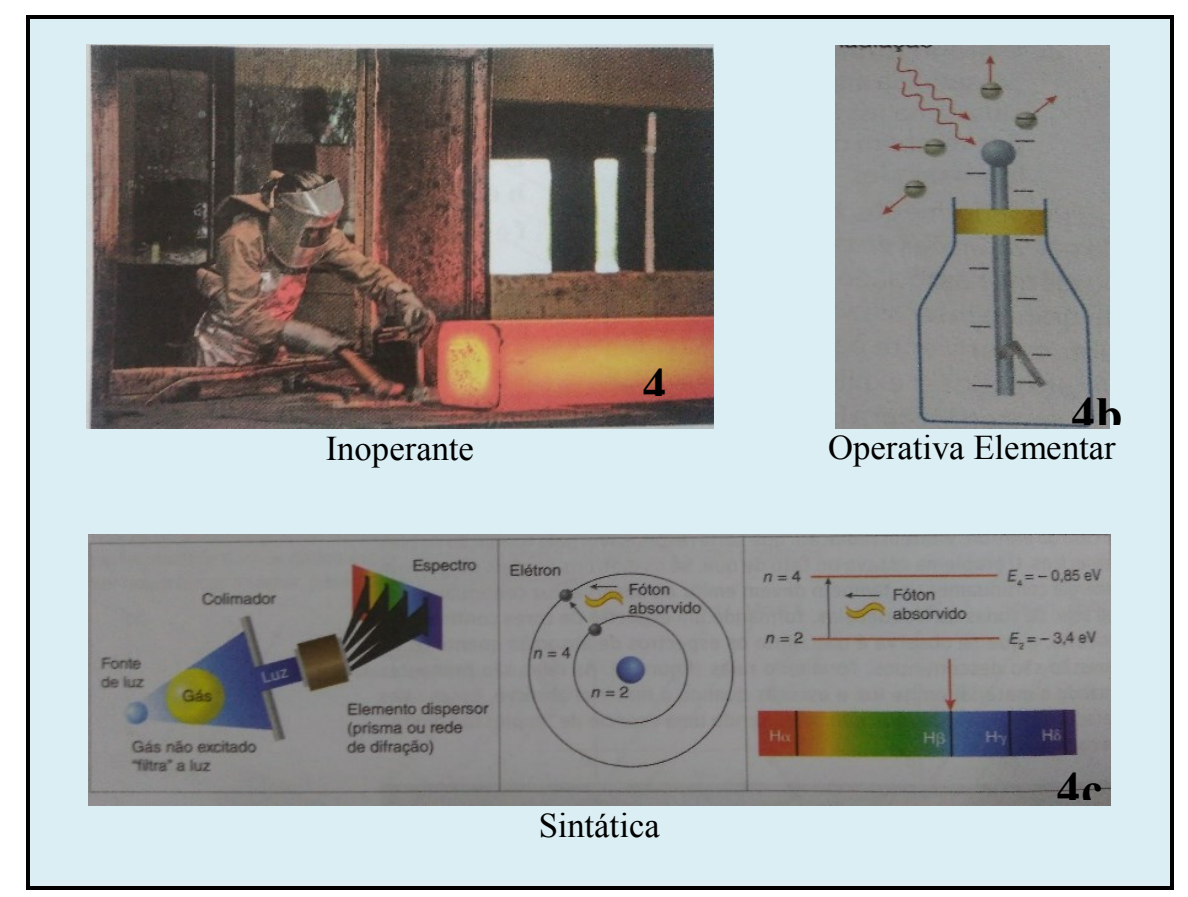

Fig. 4 - Exemplos dos recursos visuais em relação à funcionalidade das imagens. Fonte: Torres et al. (2016) (4a-Livro C); Martini et al. (2016) (4b e 4c-Livro I).

As ilustrações presentes na categoria relação com o texto principal apresentam o resultado descrito no Quadro 11 a seguir.

Quadro 11 - Relação com o texto principal.

\begin{tabular}{|l|c|c|c|c|c|c|c|c|c|c|c|c|c|}
\hline \multicolumn{10}{|c|}{ Relação com o texto principal } \\
\hline & A & B & C & D & $\mathbf{E}$ & $\mathbf{F}$ & $\mathbf{G}$ & $\mathbf{H}$ & $\mathbf{I}$ & $\mathbf{J}$ & $\mathbf{K}$ & $\mathbf{L}$ & Total \\
\hline Conotativa & 1 & 2 & 1 & 1 & & 2 & 1 & 7 & 1 & 3 & 5 & 5 & 29 \\
\hline Denotativa & 1 & 3 & 9 & 7 & 1 & 6 & 3 & 9 & 4 & 7 & 4 & 8 & 62 \\
\hline Sinóptica & 1 & 1 & 4 & 3 & & 6 & 2 & 4 & 4 & 2 & 3 & 3 & 33 \\
\hline
\end{tabular}

Fonte: Dados da pesquisa (2019).

O Quadro 11 demonstra que a grande maioria das obras distribui as suas imagens em todas as unidades elementares, concentrando a maioria na unidade elementar denotativa, correspondendo a aproximadamente $49,2 \%$ das imagens analisadas. Nessa unidade, o texto estabelece a correspondência entre os elementos contidos na ilustração e os conteúdos representados. Isso pode ser ilustrado na Fig. 5c (Livro A), a qual demonstra essa relação entre a imagem e o texto, conforme o seguinte trecho do texto principal:

Apesar de haver elétrons livres num metal, eles não conseguem 'escapar' devido à grande atração exercida pelas cargas elétricas positivas dos núcleos atômicos. $O$ resultado combinado de todas as forças envolvidas pode ser obtido supondo cada elétron preso numa barreira de energia potencial, como mostra a figura 9.20. Para 
arrancar um elétron de um metal, deve-se realizar um trabalho sobre ele, fornecendo uma quantidade de energia denominada função trabalho do metal, ET (MÁXIMO; ALVARENGA, 2016, p. 258).

Pode-se perceber que no texto principal é mencionada a imagem do fenômeno que está sendo apresentado, na passagem "quando é mostrada a Figura 9.20". Ao longo do texto, são apresentadas siglas, como por exemplo, " $E_{T}$ - função trabalho do metal", para que, ao fazer a leitura, o leitor relacione a descrição do fenômeno com o que é apresentado na imagem. Isso acontece em toda a página, na qual os autores vão inserindo o contexto histórico, aplicações do fenômeno e a apresentação do conceito do efeito fotoelétrico. Julga-se bastante importante essa relação que é feita entre o texto e a imagem para a compreensão e a interpretação do fenômeno apresentado.

A unidade elementar sinóptica, na qual a imagem e o texto formam uma unidade indivisível, representa aproximadamente $27,3 \%$ das imagens contidas nos livros. Esse dado é importante, uma vez que revela que existe uma quantidade significativa de imagens que não são apresentadas apenas de forma meramente ilustrativa, mas que apresentam um papel importante junto ao texto. A imagem 5a (Livro J) é um exemplo disso, na qual, para explicar o átomo de hidrogênio segundo o modelo atômico de Bohr, a imagem é acompanhada pelo texto, formando uma unidade. Dessa forma, para a compreensão dos níveis de energia do átomo de hidrogênio, é necessária a leitura do texto e a interpretação na imagem, assim como o texto tem sentido quando acompanhado da imagem. A combinação das imagens com o texto é bastante importante, e talvez seja essa a relação mais importante e significativa.

Ainda em relação à unidade elementar conotativa, na qual a imagem é uma ilustração sem vínculos com o texto, observa-se que é utilizada em um número menor na maioria das obras em relação às outras unidades. Esse dado revela que talvez a ilustração desvinculada do texto acaba não sendo compreendida, por isso a utilização de relações de texto e imagem. Exemplo dessa imagem é a Fig. 5b (Livro B).

Nesta categoria é possível observar que algumas obras procuram identificar, dentro do texto, a imagem a que o texto está se referindo, enquanto que outras apresentam as imagens ao longo do texto sem fazer referências a elas, estando implícito que, ao ler o texto, os elementos contidos nas imagens vão sendo relacionadas pelo leitor. São estratégias utilizadas pelos autores, que em alguns momentos favorecem e em outros, não, a relação entre o texto e a imagem. 


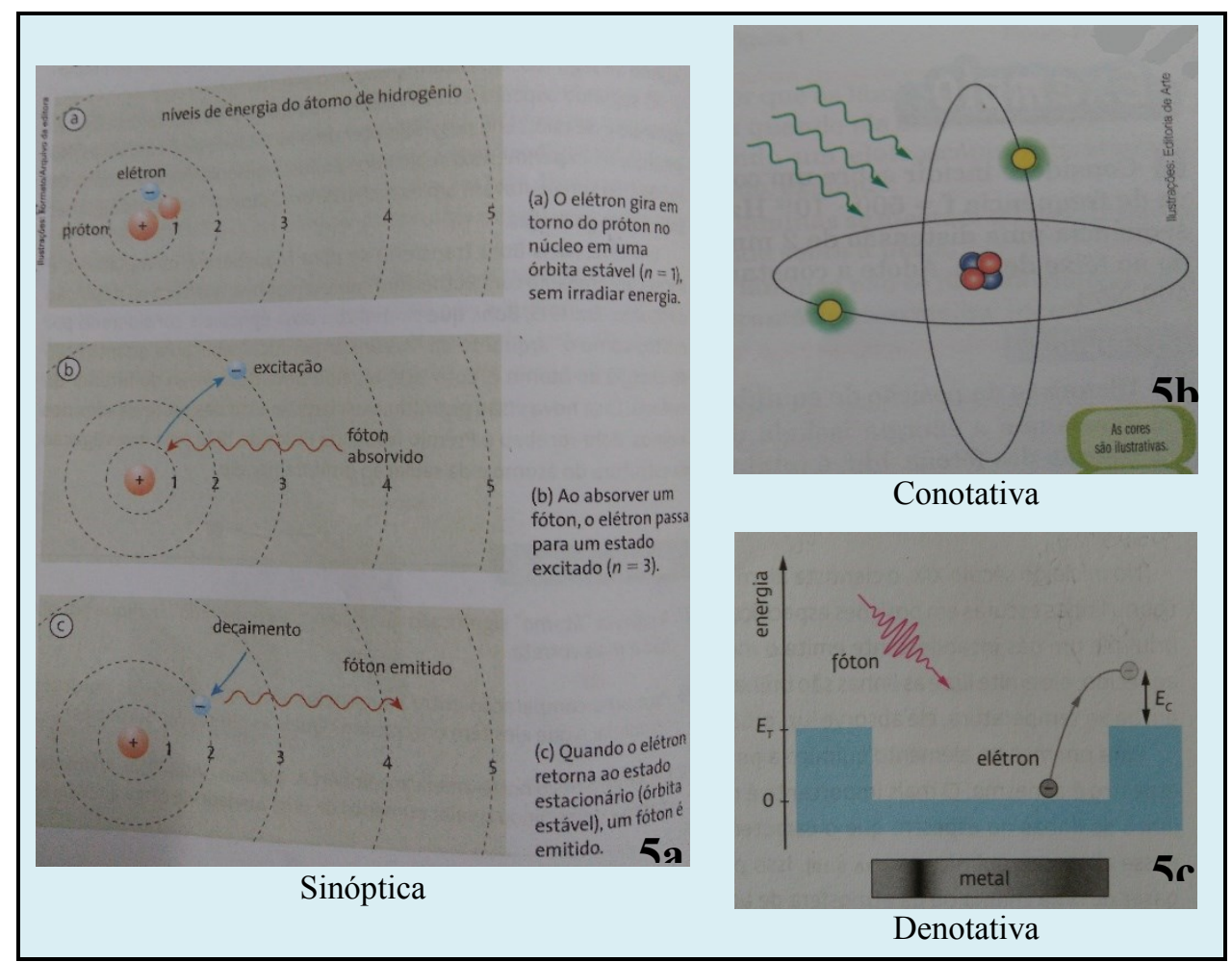

Fig. 5 - Exemplos dos recursos visuais quanto à relação com o texto principal.

Fonte: Piqueira et al. (2017) (5a - Livro J); Barreto e Xavier (2016) (5b - Livro B); Máximo; Alvarenga (2016) (5c-Livro A).

Quadro 5 - Etiquetas verbais.

\begin{tabular}{|l|c|c|c|c|c|c|c|c|c|c|c|c|c|}
\hline \multicolumn{10}{|c|}{ Etiquetas verbais } & \\
\hline & A & B & C & D & $\mathbf{E}$ & $\mathbf{F}$ & $\mathbf{G}$ & $\mathbf{H}$ & $\mathbf{I}$ & $\mathbf{J}$ & $\mathbf{K}$ & $\mathbf{L}$ & Total \\
\hline Sem etiqueta & & 2 & & & 1 & & & 6 & 1 & 1 & 1 & 4 & 16 \\
\hline Nominativa & 2 & 3 & 9 & 6 & & 11 & 3 & 10 & 3 & 9 & 6 & 12 & 74 \\
\hline Relacionável & 1 & 1 & 5 & 5 & & 3 & 2 & 4 & 5 & 2 & 5 & & 33 \\
\hline
\end{tabular}

Fonte: Dados da pesquisa (2019).

Sobre a categoria etiquetas verbais, a qual busca analisar se textos presentes na ilustração auxiliam na sua interpretação, observa-se que a maioria das obras faz uso de etiquetas verbais. Em algumas obras, como F, J e L, a maioria das etiquetas são nominativas, as quais apresentam letras ou palavras para identificar elementos da ilustração. Isso é representado na Fig. $6 \mathrm{~b}$ (livro A) em que cada elemento do experimento é destacado pela etiqueta para que o leitor possa fazer a identificação. As etiquetas relacionáveis também são utilizadas pelas obras para relacionar os elementos da ilustração, como é mostrada na Fig. 6c (Livro H). 


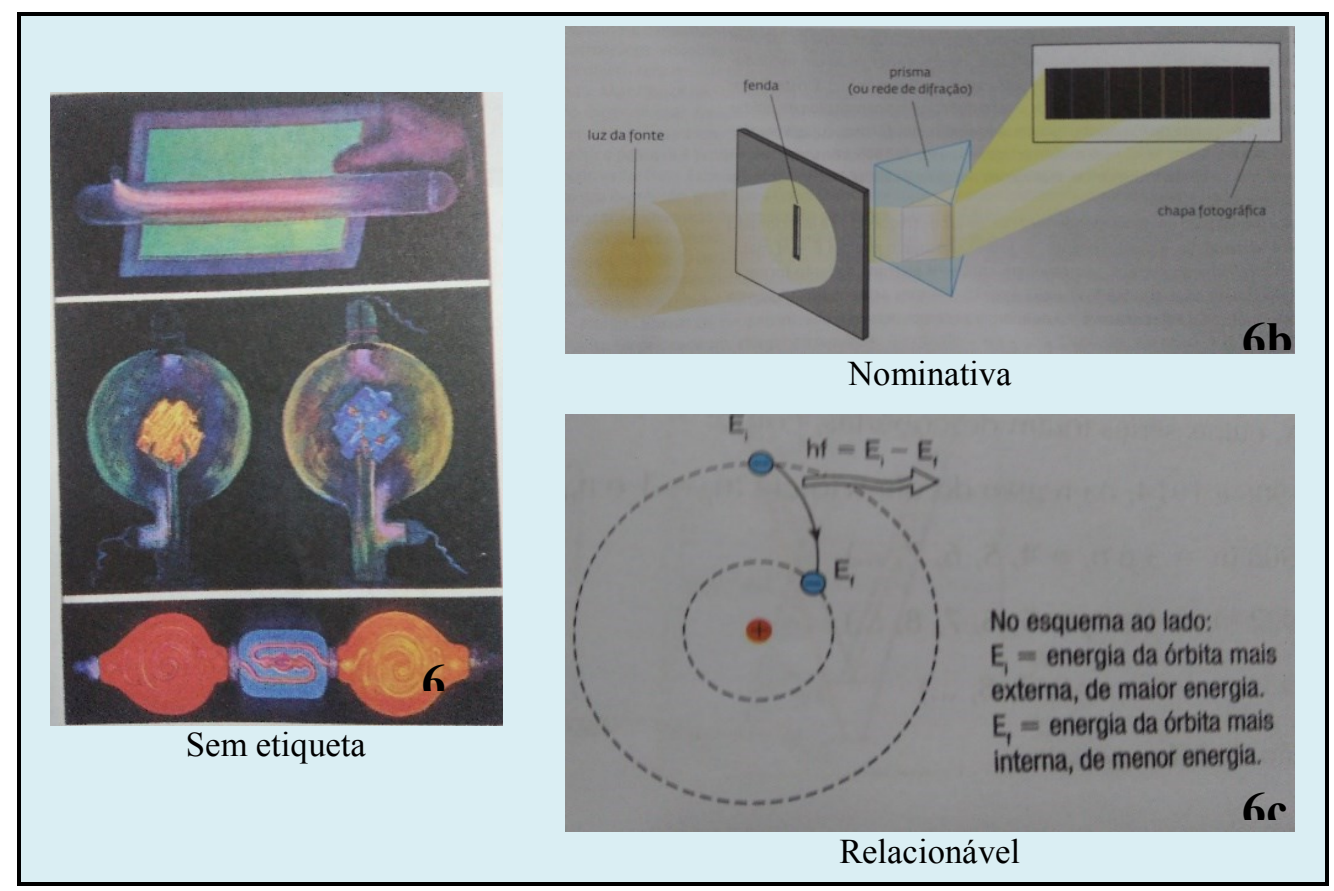

Fig. 6 - Exemplos dos recursos visuais em relação às etiquetas verbais.

Fonte: Gaspar (2016) (6a - Livro L); Máximo e Alvarenga (2016) (6b - Livro A); Bonjorno et al. (2016) (6c-Livro H).

Ainda considerando a relação do texto e as etiquetas que acompanham as imagens, observa-se que, embora a grande maioria das imagens possua símbolos, palavras ou textos para facilitar a compreensão, nem sempre isso está em consonância com o texto. Em algumas situações, as etiquetas não oferecem uma explicação adequada ou são suficientes e isso não é retomado no texto.

O Quadro 13 mostra o número de imagens utilizadas em cada obra para representar os tópicos de Física Quântica definidos para este estudo.

Quadro 6 - Unidades elementares para a análise do conteúdo científico.

\begin{tabular}{|l|c|c|c|c|c|c|c|c|c|c|c|c|c|}
\hline \multicolumn{1}{|c|}{ Etiquetas verbais } & A & B & C & D & E & F & G & H & I & J & K & L & Total \\
\hline Radiação do corpo negro & 1 & 2 & 2 & & & 2 & & 3 & & 1 & & 2 & 13 \\
\hline Efeito fotoelétrico & & 2 & 4 & 1 & & 3 & 3 & 4 & 5 & 3 & 1 & & 26 \\
\hline Modelos atômicos & & 2 & 4 & 8 & 1 & 1 & 2 & 5 & 1 & 3 & 5 & 6 & 39 \\
\hline Espectroscopia & 2 & & 4 & 2 & & 8 & 1 & 8 & 3 & 5 & 6 & 8 & 47 \\
\hline
\end{tabular}

Fonte: Dados da pesquisa (2019).

De modo geral, observa-se que nem todos os tópicos são contemplados nos livros analisados, assim como o número de imagens utilizadas para a representação desses tópicos variam. Mais especificamente, destacam-se os livros C, F, H e J como as que apresentam imagens contemplando todos os tópicos definidos pelo estudo. Por outro lado, o tópico radiação do corpo 
negro não é mencionado nos livros $\mathrm{D}, \mathrm{E}, \mathrm{G}, \mathrm{I}$ e $\mathrm{K}$, enquanto que o tópico efeito fotoelétrico não é representado nos livros $\mathrm{A}, \mathrm{E}$ e L. Já o tópico modelos atômicos não é representado na obra $\mathrm{A}$ e a espectroscopia não é ilustrada nos livros B e E.

Em relação à diferença do número de imagens utilizadas pelas obras para representar os tópicos, destaca-se que os livros D e L que utilizam oito e seis ilustrações respectivamente em referência aos modelos atômicos, enquanto que o livro A não utiliza imagens para esse tópico. Em outra situação, observa-se que os livros F, H e L utilizam oito imagens para ilustrar o tópico referente à espectroscopia, enquanto que o livro G uma única imagem.

Os resultados dessa categoria evidenciam que os livros analisados não contemplam os mesmos tópicos de Física Moderna, assim como não os apresentam da mesma maneira. A respeito disso, Dominguini $(2012$, p. 6) coloca que "os autores dão pesos diferentes à importância desse conteúdo". Segundo ele, alguns autores dos livros didáticos consideram a Física Moderna como um conteúdo imprescindível aos alunos, enquanto outros a consideram apenas como leituras complementares. Essa concepção faz com que em algumas obras haja unidades específicas, capítulos ou apêndices e textos complementares para a sua abordagem.

\section{Considerações finais}

As imagens constituem um importante recurso pedagógico para a aprendizagem, especialmente ao ensino de Física. Nesse contexto, o livro didático torna-se um importante veículo para a divulgação dessas imagens, dada a sua importância no contexto escolar. Todos esses elementos fomentaram a realização desse estudo que teve por objetivo avaliar como as imagens estão sendo utilizadas pelos autores dos livros didáticos de Física do ensino médio em Física Quântica.

Para nortear a análise do estudo tomou-se como referencial a taxonomia proposta por Perales e Jiménez (2002), a qual avalia a adequação das imagens em livros de ciências. Tais categorias se referem a: sequência didática (como as imagens são utilizadas ao longo do texto), iconicidade (grau de complexidade da imagem); funcionalidade (a função da imagem no entendimento do conceito); relação com o texto (referências mútuas entre texto e imagem); legendas verbais (textos incluídos nas ilustrações) e conteúdo científico (as imagens se apoiam ou não em representações chave para a correta interpretação dos fenômenos). Menciona-se que a utilização dessas categorias se mostrou bastante importante para a compreensão do modo como são apresentadas as imagens nos livros didáticos e o seu papel frente à compreensão dos conceitos.

Os resultados evidenciados no estudo permitiram identificar três aspectos importantes relativos ao uso do recurso visual nos livros didáticos, a saber: o primeiro aspecto refere-se à função dada à imagem no texto, sobre a qual é possível inferir que a sua função está em ajudar o estudante a vincular o aprendizado dos conceitos relativos à Física Quântica às imagens mentais específicas criadas a partir das representações utilizadas nos livros didáticos; o segundo aspecto diz respeito ao elevado grau de complexidade em que as imagens são apresen- 
tadas nas obras. A respeito disso, menciona-se que tais imagens tendem a ser apresentadas de modo a relacionar elementos simbólicos e figurativos para representar os conceitos, o que denota a necessidade de uma compreensão maior por parte do estudante; e o terceiro trata-se da pouca ou falta de relação existente entre o texto e as imagens, assim como a relação entre as etiquetas que acompanham as imagens com o texto. Essa falta de relação acaba por vezes fazendo com que a imagem não contribua de forma significativa para a compreensão do conceito.

Cabe mencionar que tais resultados representam importantes contribuições para a compreensão e discussões a respeito de como as representações têm permeado os livros didáticos, no que tange o tópico de Física Quântica. Julga-se importante considerar que ainda há outros aspectos que precisam ser elucidados, e que não foram contemplados neste estudo, necessitando de mais pesquisas sobre esta temática.

Por fim, destaca-se que a utilização uma imagem por si só não é capaz de transmitir tudo o que pretende, e isso precisa ser considerado no processo de aprendizagem. É necessário, especialmente no ensino de Física Quântica, um olhar atento às imagens que de fato contribuem para o entendimento do fenômeno. Neste sentido, o professor, ao realizar a escolha do livro didático, deve levar em consideração os aspectos relacionados à forma como as imagens são abordadas. Também é de grande importância que isso se reflita no trabalho em sala de aula, pois a imagem tem um papel bastante importante no processo de ensino, mas precisa ser trabalhada com cautela, para que não seja apenas uma ilustração ou se transforme em um obstáculo.

\section{Referências}

ARAÚJO, J. C.; FERNANDES, M. J. C.; SILVA JUNIOR, O. F. Construções geográficas: teorizações, vivências e práticas. Duque de Caxias, RJ: Espaço Científico Livres Projetos Editoriais, 2013.

BARRETO, B.; XAVIER, C. Física aula por aula. 2 ed. São Paulo: FTD, 2016.

BIAZUS, M. O. Tópicos de Física Moderna e Contemporânea no ensino médio: interfaces de uma proposta didática para mecânica quântica. 2015. Dissertação (Mestrado em Ensino de Ciências e Matemática) - Universidade de Passo Fundo, Passo Fundo.

BISCUOLA, G. J.; VILLAS BÔAS, N.; DOCA, R. H. Física. 3 ed. São Paulo: Saraiva, 2016.

BONJORNO, J. R. et al. Física. 3 ed. São Paulo: FTD, 2016.

BRASIL. Ministério da Educação. Base Nacional Comum Curricular. Ministério da Educação, Brasília, DF: MEC, 2017. Disponível em: 
$<$ http://basenacionalcomum.mec.gov.br/images/BNCC_EI_EF_110518_versaofinal_site.pdf.>. Acesso em: 29 out. 2019.

CHAVES, F. G. Uma proposta de inserção de conteúdos de Mecânica Quântica no ensino médio, por meio de um curso de capacitação para professores em atividade. 2010. Dissertação (Mestrado em Ensino de Ciências) - Programa de Pós-Graduação em Ensino de Ciências, Universidade de Brasília, Brasília.

DARROZ, L. M.; ROSA, C. T. W.; GIARETTA, P. H. O uso de imagens esportivas no ensino de mecânica: uma análise nos livros didáticos de Física. Investigações em Ensino de Ciências, Porto Alegre, v. 22, n. 3, p. 125-144, 2017.

DOMINGUINI, L. Física moderna no Ensino Médio: com a palavra os autores dos livros didáticos do PNLEM. Revista Brasileira de Ensino de Física, São Paulo, v. 34, n. 2, 2502, 2012.

FERREIRA, R. M. Física Moderna: divulgação e acessibilidade no ensino médio através das histórias em quadrinhos. 2013. Dissertação (Mestrado em Ensino de Ciências e Matemática) Programa de Pós-Graduação em Ensino de Ciências e Matemática, Universidade Federal de Alagoas, Maceió.

FUKE, L. F.; YAMAMOTO, K. Física para ensino médio. 4 ed. São Paulo: Saraiva, 2017.

GARCIA, T. M. F. B. Cotidiano escolar, livros didáticos e formação docente. In: FONSECA, S.; GATTI JR., D. (Orgs.). Perspectivas do ensino de História: ensino, cidadania e consciência histórica. Uberlândia: Edufu, 2011, p. 361-371.

GASPAR, Alberto. Compreendendo a Física. 3 ed. São Paulo: Ática, 2016.

GONÇALVES FILHO, A.; TOSCANO, C. Física: interações e tecnologia. 2 ed. São Paulo: Leya, 2016.

GIACOMELLI, A. C. Teoria da relatividade: uma proposta didática para o ensino médio. 2016. Dissertação (Mestrado em Ensino de Ciências e Matemática) - Universidade de Passo Fundo, Passo Fundo.

LAJOLO, M. Livro didático: um (quase) manual de usuário. Em Aberto, Brasília, v. 16, n. 69, p. 3-9, 1996. 
MACHADO, D. I.; NARDI, R. Construção de conceitos de física moderna e sobre a natureza da ciência com suporte da hipermídia. Revista Brasileira de Ensino de Física, São Paulo, v. 28, n. 4, p. 473-485, 2006.

MARTINI, G. et al. Conexões com a Física. 3 ed. São Paulo: Moderna, 2016.

MARTINS, I.; GOUVÊA, G.; PICCININI, C. Aprendendo com imagens. Ciência e Cultura, v. 57, n. 4 , p. $38-40,2005$.

MÁXIMO, A.; ALVARENGA, B. Física: contexto a aplicações. 2 ed. São Paulo: Editora Scipione, 2016.

MONTEIRO, I. G.; JUSTI, R. S. Analogias em livros didáticos de Química brasileiros destinados ao ensino médio. Investigações em Ensino de Ciências, Porto Alegre, v. 5, n. 2, p. 67 91, 2000.

MORAES, J. U. P. O livro didático de Física e o ensino de Física: suas relações e origens. Scientia Plena, Aracaju, v. 7, n. 9, p. 1- 4, 2011.

OliveirA, J. B. A.; GuimarÃes, S. D. P. A Política do livro didático. 2. ed. São Paulo: Summus Editora, 1984.

OSTERMANN, F.; MOREIRA, M. A. Updating the physics curriculum in high schools: a teaching unit about superconductivity. Revista Electrónica de Enseñanza de las Ciencias, Vigo, v. 3, n. 2, p. 190-201, 2004.

OTERO, M. R.; GRECA, I. M. Las imágenes en los textos de Física: entre el optimismo y la prudencia. Caderno Brasileiro de Ensino de Física, Florianópolis, v. 21, n. 1, p. 35-64, 2004.

OTERO, M. R.; MOREIRA, M. A.; GRECA, I. M. El uso de imágenes en textos de física para la enseñanza secundaria y universitaria. Investigações em Ensino de Ciências, Porto Alegre, v. 7, n. 2, p. 127-154, 2002.

PERALES, F. J. Uso (y abuso) de la imagen en la enseñanza de las ciencias. Enseñanza de las Ciencias, Barcelona, v. 24, n. 1, p. 13-30, 2006. 
PERALES, F. J.; JIMÉNEZ, J. D. Las ilustraciones en la enseñanza-aprendizaje de las ciencias. Análisis de libros de texto. Enseñanza de las Ciencias, Barcelona, v. 20, n. 3, p. 369386, 2002.

PIETROCOLA, M. et al. Física em contextos. São Paulo: Editora do Brasil, 2016.

PIQUEIRA, J. R. C.; CARRON, W.; GUIMARÃES, J. O. S. Física. São Paulo: Ática, 2016.

SANTOS, V.A.; MARTINS, L. A importância do libro didático. Revista Candombá, Salvador, v. 7, n. 1, p. 20-33, 2011.

SILVA, J. A.; KAWAMURA, M. R. D. A natureza da luz: uma atividade com textos de divulgação científica em sala de aula. Caderno Brasileiro de Ensino de Física, Florianópolis, v. 18, n. 3, p. 317-340, 2001.

TERRAZZAN, E. A. Perspectivas para a inserção da Física Moderna na escola média. 1994. Tese (Doutorado em Educação) - Programa de Pós-Graduação em Educação, Faculdade de Educação, Universidade de São Paulo, São Paulo.

TORRES, C. M. et al. Física: ciência e tecnologia. 4 ed. São Paulo: Moderna, 2016.

VÁLIO, A. B. M. et al. Ser protagonista: Física. 3 ed. São Paulo: Edições SM, 2016.

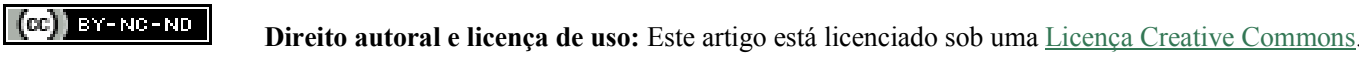

